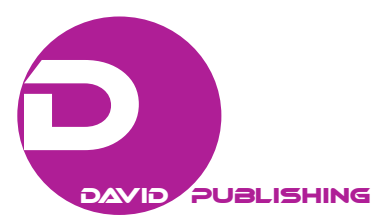

\title{
Economic and Financial Viability in Spanish Thermal Power Station
}

\author{
Sérgio Paiva \\ Universidade Federal de Mato Grosso do Sul, Campo Grande, Brazil \\ Alfonso Redondo Castán, Gregorio Antolín Giraldo \\ Universidad de Valladolid, Valladolid, Spain
}

This article tracked, identified, and demonstrated the economic and financial viability of the renewable energy sector from biomass in a Spanish Thermal Power Plant. The methodology used came from Theoretical postulates (GITMAN, 2004; VAN HORNE, 1993) called, Technical Preparation of capital budgets (Economic and Financial Analysis) called, payback, Net Present Value, and Internal Rate of Return). The economic and financial viability results demonstrated were in two stages: the first identified that the plant is viable according to the payback. The second traced the economic and financial viability from the thermal energy production hypothesis equivalent to electricity power in the amount of 7,699.08 $\mathrm{MWh}$, which resulted in the following indicators: payback of seven years and three months, NPV of R\$369,064.98, and the IRR of $12.46 \%$. Therefore, managers would have to make a user raising campaign in the ratio of $24.66 \%$, taking into account of an unused capacity of $25 \%$. These indicators were calculated using the following financial data: initial investment of $\mathrm{R} \$ 3,654,731.86$, operational income of $\mathrm{R}$ $\$ 1,262,264.16$, operational inputs of $\mathrm{R} \$ 503,639.59$, and capital cost of $10.95 \%$ over 20 years. This industrial plant is located in the city of Cuellar in northern Spain, having two employees working eight hours a day; it produces only thermal power, represented in this study by MWh of electric power. This industrial plant produces power by burning forest residues from tree pruning. It was concluded that, given the research question developed in this paper - is the study plant profitable from the economic and financial point of view? - The response was identified by calculating the economic and financial indicators that the plant studied is viable from the proposed of maximizing sales revenues to 7,699.08 MWh.

Keywords: economic and financial viability, renewable energy, biomass, financial analysis, investment analysis, thermal power

\section{Introduction}

This paper analyzes the economic feasibility of renewable energy from biomass in an industrial plant, called "thermal central industrial plant" (also called plant II), located in the Autonomous Community of Castilla y León, in northern Spain, it produces only thermal energy, represented in this study by MWh of

Sérgio Paiva, adjunct professor, Ph.D., Universidade Federal de Mato Grosso do Sul, Av., Brazil.

Alfonso Redondo Castán, associate professor, Ph.D., Universidad de Valladolid, 47011-Valladolid, Spain.

Gregorio Antolín Giraldo, associate professor, Ph.D., Universidad de Valladolid, 47011-Valladolid, Spain.

Correspondence concering this article should be addressed to Universidade Federal de Mato Grosso do Sul, Av. Costa e Silva, s/n-Cidade Universitária, 79070-900-Campo Grande, Brazil. 
electricity. This plant II produces energy from forest residues from tree pruning (pine).

This plant consists of two boilers of mobile grates, which are usually used separately, one in the winter and the other in the summer. Most have power of 4,500,000 kcal/h, only being used in winter to provide heating for the users: condominiums (apartments), high school, and some municipal facilities of the city of Cuellar. The process is carried out in winter by heating in a pool that is done at night because of the Thermal Inertia of the water used in solar thermal energy input to keep the pool heated during the day (water system of renewable energy). As the smallest has $600,000 \mathrm{kcal} / \mathrm{h}$, which provides services ACS (hot water) during the summer for the same premises and aforementioned conditions, working as an assistant of the first. The yield of the two boilers is approximately $60 \%$ of the installed potential. The system efficiency is achieved by the use of secondary combustion air (large and small boiler) and tertiary (large boiler), both preheating the smoke outlet (vent).

The hot water system of the plant is closed, because the water is sent to the residences or buildings at $90{ }^{\circ} \mathrm{C}$. Thus, the distribution network comprises a double tube, which leads the hot water to the users and after use, returns water practically at a temperature between 85 and $65{ }^{\circ} \mathrm{C}$ (depending on the time of the day energy consumption) natural to the central distribution. This primary circuit of hot water distribution is composed of a pre-isolated pipe, which is one meter deep along the city streets. Thus, when no heat consumption occurs a maximum loss of $0.5^{\circ} \mathrm{C}$ over the entire network, which has approximately $3 \mathrm{~km}$ of dimension.

The analyzed plant consists of two employees who worked eight hours a day, according to the country's legislation in 2009 (DIEESE, 2012). It is worth mentioning that the analysis period was 358 days, from 21-11-2008 to 14-12-2009.

The studied plant was established through a project with an initial investment of $\mathrm{R} \$ 3,654,731.86$, equivalent to $€ 1,465,116$ (EUR), with recovery period of initial investment maximum of 20 years. Operating costs were measured only within the power station, i.e., all the financial resources consumed in the production process of thermal energy (hot water). It is noteworthy that the costs of field process (grinding of biomass, freight, fuel, and lubricant) were not included in the calculation of the operating costs. Thus, in this study were treated as operating costs only production costs within the plant biomass thermal center.

This article proposes to demonstrate the economic and financial viability of an industrial plant in the renewable energy segment. Therefore, this research tracked, identified, analyzed, and demonstrated the profitability of the plant, considering the capital analysis techniques (payback, Net Present Value, and Internal Rate of Return), taking into account of its opportunity cost. In addition, a proposal for maximizing sales revenue to solve the infeasibility problem of the studied plant was developed, having as goal, full profitability. It is important to emphasise that this paper is relevant to the financial management framework applied to renewable energy because it deals with the profitability of the projects of economic and financial point of view, but precisely in the financial area related to operating costs and their inputs (sales income) in a small industrial plant with capacity of $5.9 \mathrm{MW} / \mathrm{h}$. Although there are similar researches published in the renewable energy segment, e.g., Creus (2009), which showed that the thermoelectric units with a capacity of $20 \mathrm{MW} / \mathrm{h}$ are not feasible from an economic and financial point of view, but brings no solution to the problem of non-profitability of the business, which could propose an increase in sales income or reduction in operating costs.

The objectives of this paper were to track, identify, analyze, and demonstrate the economic viability of the renewable energy sector from biomass in a Spanish Thermal Power by the Capital Budgeting Technique (Economic and Financial Analysis) called payback, Net Present Value, and Internal rate of return (GITMAN, 2004; VAN HORNE, 1993). 
This article is divided into Literature Review, Research Methodology, Research Result, and Conclusion.

The literature review expatiates on the economic and financial key concepts, according to Van Horne (1993); Gitman (2004); Emery and Finnerty (2000); Johnson and Melicher (1989); Ramírez Rojo (2011);. Ramírez Rojo (2011); Emery and Finnerty (2000) among other references correlated to the studied subject.

The research methodology was outlined this study as Case Study, having as theoretical basis the description of Yin (2001). This author states that the case study is more appropriate to test well-founded theories, e.g., the capital budget preparation techniques (Average Rate of Return, Payback Time, Net Present Value, and Internal Rate of Return) (Gitman, 2004; Van Horne, 1993).

The research results are presented in tables from the following data: revenues were from private buildings cooperatives origin of $\mathrm{R} \$ 777,177.35$ (Table 5), which represented $79.66 \%$ of total revenues of the analyzed period, related to the period from 11-21-2008 to 12-14-2009, equivalent to 358 days. The total of operating costs was exposed in Table 4, in the amount of $\mathrm{R} \$ 758,624.57$.

In the conclusion, it was found that the economic and financial viability was identified from thermal power production proposal equivalent to 7,699.08 $\mathrm{MWh}$, which resulted in the following indicators: payback time of eight years and three months, NPV of R $\$ 369,064.98$ and IRR $12.46 \%$. Thus, managers would have to make a user raising campaign on the order of $24.66 \%$, taking into account of an unused capacity of $25 \%$. This scenario would only be achieved through the following financial data: initial investment of R\$3,654,731.86, operating income of $\mathrm{R} \$ 1,262,264.16$, operational inputs of $\mathrm{R} \$ 503,639.59$, and capital cost of $10.95 \%$ over 20 years.

\section{Literature Review}

From the point of view of economic management, the company is a basic unit of production of goods and services, representing a set of human and material elements for the same purpose: the realization of a typically economic benefit (production). According to economic philosophy, in a context of market economy, the company seeks a general practice, understood as the buying and selling of goods and services in all countries of the world (ÁLVAREZ, 1992). Thus, economic management is approached with extreme relevance in the contemporary business environment, especially for decision-making purposes. Reinforcing this concept of management, Ruíz Martinez (2001) states that, in general, financial management organizes and guides the financial transactions in accordance with the company's objectives, which generally are associated with the core activity of the business unit, promoting a discussion with different points of view between profit maximization and the company's value.

Given this management context, according to Van Horne (1993), to make rational decisions in accordance with the company's goals, the administrator needs certain analytical hierarchies, such as the efficiency in managing the assets and the accounting information (such as depreciation). The efficiency in managing assets may be associated with efficiency in identifying them and controlling them. According to Martins (2003), the assets are identified as physical and logical objects that have some value to the business process of the company. Among the physical objects are those like hardware, buildings, and others; whereas, as for the logical objects are included objects such as, software, database, among others.

From an accounting point of view, the company can be treated also as an organization composed of both assets and rights and as of obligations. This accounting business composition requires an efficient and secure management to validate the second principle of accounting, called the Continuity Principle, which aims to 
establish business continuity. Therefore, organizations elaborate plans that can ensure the continuity and growth of companies in the same way (as a minimum) the growth of the country of origin of the organization. Thus, the business units address the financial area as one of the most sensitive in the business scenario environments, developing financial planning through the analysis of companies' cash flows in general, which could be used to plan the tendencies of the various investments such as the initial investment recovery period, value of the initial investment etc. (VAN HORNE, 1993).

It is worth adding that the financial environment companies can be determined as follows: where the company is, in which position it is at the present moment and where it goes. This refers both in the most likely positive developments, as in the negative facts of economic and financial point of view in the pursuit of profit maximization (VAN HORNE, 1993).

Financial theory addresses three important areas, according to Emery and Finnerty (2000): corporate financial management, financial investments (investment), and capital markets. The first area is focused on the strategies on how to create and maintain value in their roles (actions). The second area (financial investments) addresses investments (financial investments) after examining all investment projects, choosing the investments that possibly can attract new investors in their business environment. Finally, the third area relates to the financial theory that discusses the capital markets, called financial markets by buying and selling of financial instruments such as stocks, bonds, among others.

In Emery and Finnerty's vision (2000), the maximization of profits companies can be the main objective and only of the owner-manager. In this sense, it can be said that economic theory assigns the use of tactical planning promotes economic benefit (companies value), which could be achieved through the company's efficiency and also by the identification of participation of entrepreneur or manager-owner, who could seek profit maximization.

This discussion regarding financial planning may reflect the equity of the business unit. Along the same ideas express Johnson and Melicher (1989) and Ramirez Rojo (2011). Johnson and Melicher (1989) stated that financial resources should be reversed (consumed) in fixed assets from projects that receive income at least equal to the capital cost of funds raised and absorbed in a supposed project in economic and financial evaluation. Moreover, the contemporary economic and financial management suggests that decisions could be taken as the basis of financial indicators such as the percentage of current assets in a given period. This management is supported by the techniques of capital budgets. Ramirez Rojo (2011) mentions that the traditional analysis of economic and financial data of companies has been carried out based on allotments, i.e., the ratio for coefficient between two simple or compound magnitudes, e.g., payback.

In this sense, business projects could be evaluated by the capital budget techniques after the preparation of their cash flows. Gitman (2004) contributes stating that the three capital budgeting techniques most used in the business environment are: (i) payback; (ii) net present value (NPV); and (iii) internal rate of return (IRR).

The first technique (payback) is the time required for the company to recover the initial investment of a particular investment (project) and can be used in investment project evaluations. The payback is derived from dividing the initial investment by the sum of operating inputs (operating income), establishing time as a decision criteria. Thus, if the payback period is less than the maximum acceptable recovery period that was set by the financial manager of companies, the project from the theoretical point of view could be rejected, i.e., would not be accepted; whereas if the payback period is longer than the maximum acceptable period, the project could be accepted (GITMAN, 2004). 
The payback is treated as a method that identifies the period of recovery of the initial investment by the sum of the operating cashflow, i.e., the operational inputs minus those outputs from the respective project. The result of this method is obtained by dividing the initial investment by the operating results related to project cash flow.

The payback on the one hand, presents itself as a very useful method in situations of high uncertainty in investments or there is no knowledge of the exact time of the start of operation of the investment. Thus this method provides information about the minimum time required to recover the initial investment. On the other hand, this method does not provide any profitability measure and does not take into account of the time of the various cash flows generated by the projects. Furthermore, it is not taken into account of the positive cash flows that could possibly occur after the initial recovery period.

The payback calculation formula is shown as follows (REDONDO and PAJARES 1999):

$$
P \& B=\frac{\sum A}{\sum \mathrm{Q}}
$$

Subtitle:

$\Sigma A=$ initial investment sum plus the possible flows of negative cases

$\Sigma Q=$ sum of all positive cash flows generated by the project.

The payback has criteria for choosing projects treated as more relevant from investments with less recovery period (REDONDO \& PAJARES, 1999).

The second capital budgeting technique (net present value) is obtained by subtracting the initial investment by the sum of operating inputs (operating income), discounted to the capital cost of the analyzed period of a given project (GITMAN, 2004). This technique effectively considers the value of money over time in view of the interest rate established by the company, which can be referred in different ways, taking into account of the project situation: discount rate, required return, capital cost, opportunity cost, among others. A capital cost equal to the IRR allows the minimum return that must be achieved in a project so that the market value of the company (shares) remains stable. Below is the formula of Net Present Value-NPV (GITMAN, 2004):

$$
N P V=\sum_{t=1}^{n} \frac{C F^{t}}{(1+i)^{t}}-C F O
$$

Subtitles

$\sum_{t=1}^{n}=$ Sum of the periods where $t=1$;

$N P V=$ Net Present Value;

$C F t=$ Operating input or operating income in a given period;

$(1+i)^{t}=$ One plus $(1+)$ cost of capital to the period power;

$C F_{0}=$ Initial investment or current investment.

The above expression shows the formula calculated by the present value of cash inflows minus initial investment. From these quantitative data, the NPV is estimated as follows: if it is greater than zero, it is suggested that the project could be accepted; whereas if the NPV is less than zero, it is suggested that the project should be rejected. 
Following Gitman's thought (2004), Emery and Finnerty (2000) state that the projects could be evaluated by the criterion of the net present value ${ }^{1}$ (NPV), which calculates the present value of all net flows, being related to the alleged project evaluation. To do so, it uses the operating result or operating income (the difference between revenues minus operating costs). The project could be implemented if the result of the NPV is positive (operating revenues would have to be greater than the operating costs). From the operating income result deducts the capital cost stipulated in a project in evaluation.

Redondo and Pajares (1999), the purpose of the net present value is to evaluate the feasibility of investment projects by calculating the sum of the cash flows of the present value (this indicator is widely used in studies of feasibility analysis). Current value is understood as the present value of a certain amount (future value). Investments may only generate cash flows in the future, which are necessary to update this value to compare them with the initial investment. If the initial investment is less than the present value of cash flows, the NPV is positive and represents that the project is viable from a financial point of view.

To update the future cash flows it is used a rate that is called discount rate or risk-free interest rate, added to an instituted risk premium for the project in question. The third technique (internal rate of return-IRR) is understood by Gitman (2004) as the most sophisticated capital budgeting technique. This is a discount rate that equates the NPV of an investment opportunity equal to zero, i.e., when the sum of the present value of the operational input is equal to the initial investment. The IRR decision criterion is performed before the comparison with the capital cost or return required by capital providers. Thus, the project could be accepted if the IRR is greater than the capital cost or rejected if the IRR is less than the capital cost. For the author, the IRR can be obtained from the following formula (GITMAN, 2004):

$$
0=\sum_{t=1}^{n} \frac{C F^{t}}{\left(1+I R R^{t}\right)}-C F O
$$

Subtitle:

$\sum_{t=1}^{n}=$ Sum of the periods where $t=1$;

$C F t=$ Operational input or operating income in a given period;

$(1+\mathrm{IRR})=$ One plus $(1+)$ the internal rate of return represented by the capital cost to the period power;

$C F_{0}=$ Initial investment or current investment.

Emery and Finnerty (2000) mention that the projects could also be measured by the internal rate of return (IRR). For this, the decision criterion is based on the result of the IRR and the capital cost. So the project could be implemented if the calculated IRR was greater than the capital cost stipulated by the project. Next, the last of the capital budgeting techniques will be calculated, this is called internal rate of return (IRR), which equals to the NPV of a project to zero, i.e., the present value of cash inflows equals to the initial investment. This is the compound rate of annual return that the company would get if implanted a supposed project.

Demonstrating a complementary vision Gitman (2004), Van Horne (1993) adds the average yield rate in the assessment of projects and maintains other analysis criteria similar to Gitman (2004). Van Horne (1993) uses the term "recovery period" as equivalent to Gitman's payback (2004). According to Van Horne (1993) the project evaluation criteria are presented as: (i) the average income rate; (ii) recovery period; (iii) internal rate of

\footnotetext{
1 This designation Emery and Finnerty (2000) is equivalent to the "Net Present Value" of Gitman (2004).
} 
return (IRR) and (iv) net present value (NPV).

The Average Income Rate is the ratio of average annual utilities after calculating the income tax. See an example: the purchase of new equipment in the amount of $\mathrm{R} \$ 20,000.00$, with an average annual income, after deducting income tax of $\mathrm{R} \$ 3,000.00$. To calculate the rate, it is asked to divide the average annual income ( $R \$ 3,000.00$ ) by $\mathrm{R} \$ 20,000.00$ (initial investment), obtaining $15 \%$ of the project rate of return. The recovery period of a project seeks the number of years required to recover the initial investment. An example is noted: initial investment of $R \$ 20,000.00$, divided by the sum of operating inputs of $R \$ 5,000.00$, obtaining four years. This means that the company would need up to four years to recover the initial investment.

These first two project evaluation criteria proved to be limited when concerning the results, it does not take into account of the value of money over time. Then the evaluation criterion by the Internal Rate of Return (IRR), which the rate equates to the net present value to zero. This IRR acceptance criterion can be based on a comparison of the capital cost of the project with the result of IRR. Thus, when the IRR presents greater when compared to capital cost, it is suggested that the project should be accepted; otherwise, it should be rejected. The last criterion of investment evaluation indicated by Van Horne (1993), known as Net Present Value (NPV), brings all operational inputs to the period zero, discounted to the capital cost of a project evaluation. Redondo and Pajares (1999) add that the IRR uses general criteria to see if it is feasible the implementation of a given project, as follows:

If $I R R \geq$ than the capital cost it is suggested that the project is accepted. This is justified because the project is more profitable than the minimum return required by the company;

If $I R R \leq$ than the capital cost supposedly the project is rejected. The reason for the rejection is that the project generates a lower return than the minimum required by the company.

It is important to mention that for Gitman (2004), there may be conflicts between the decision criteria of IRR and NPV. On the one hand, from the theoretical point of view, the NPV is the best decision to approach the capital budget because of the possibility of reinvestment of Cash Intermediate Inputs to the Capital Cost of the company; while the IRR can be an aggravating when regarding the evaluation of unconventional Cash Flow. In this case, the application of this rate could present two IRR (two different results in the same equation) or an equation without a solution, that is, not at IRR. On the other hand, from the empirical point of view, financial managers may have a particular preference for the use of the IRR in relation to NPV. This is due to the general willingness of executives to rates of returns, not to the monetary returns. Thus, interest rates, return rates, and other ways to measure the return are more used to express the annual rates of return. In this case, the use of the IRR would make more sense for financial decisions makers. They prefer the NPV because it is less intuitive and supposedly does not measure benefits in relation to the applied amount (GITMAN, 2004).

To elaborate an investment project, besides the operational inputs and operational outputs, it should inform the capital cost through the discount or return rate required by the owners. It should be noted that the capital cost of companies can be termed as cost of equity or third party capital, depending on the business environment.

Regarding the cost of equity, Ross et al. (2009) state that the discount rate of a project should be the expected return of a similar risk of equipment financed. In the view of Gitman (2004), the cost of equity is the rate of return that a company must generate projects that are being implemented to maintain the market value of its shares. This concept can also be considered from the point of view of capital providers, who require a rate of return on their membership investment. 
Regarding the Spanish scenario of renewable energy, specifically, through the biomass, which corresponds to approximately $3.655 \mathrm{TOE}$ of heat consumption, of forest origin, representing $1.4 \%$ of total power generation in the country, although the production process of a large part of this production was considered inefficient, due to the use of obsolete equipment. Thus, the energy source from biomass in Spain, on the one hand, there are industrial equipment that can be considered obsolete, as boilers, on the other hand, with the advent of mechanization in the field, it has been developing high technology equipment, used in the extraction and preparation of biomass for the combustion process in boilers. Moreover, Spain is also developing modern technologies for the use of biomass for specific thermal energy for buildings. It is gassing in ORC cycles (Organic Rankine Cycle) used in the implementation of cogeneration in buildings (IDAE, 2011). EurObserv'ER (2012) adds affirming that solid biomass produced in Spain was 4.535 Mtoe in 2010 and 4.813 Mtoe in 2011. Of this amount were consumed 3.65 Mtoe in 2010 and 3.77 Mtoe in 2011.

Regarding the energy potential of Spain, it is estimated an availability of 88 million tons of green primary biomass, including forest and agricultural residues. In addition, it can be added 12 million tons of dry biomass obtained from secondary agroforestry origin of waste, totaling about 100 million tons of biomass, which could be transformed in renewable and clean energy.

To compose the scene of Spanish renewable energy, it is important to mention energy from the sea, which generally has high generation costs and therefore is not currently available, neither it is expected to market in the medium term. Whereas, it is estimated a possible exploitation of this source in the long term, on the "Cantabrian" coast and in the north of the Canary Islands, taking into account of the emergence of new technologies that could make it viable from the economic and financial point of view (IDAE, 2011).

To complete the exposure scenario of renewable energy in Spain has shown that the supply from biomass represented $1.40 \%$ of the total generation of electricity from renewable energy in the country, although there is a potential to be exploited around 88 million tons of green primary biomass, including forest and agricultural residues, another 12 million tons of dry biomass obtained secondary agroforestry origin of waste, totaling about 100 million tonnes.

These clean energy faces obstacles caused by low-tech or even obsolete technologies of industrial equipment used. Whereas, regarding the management of biomass in the field, the country is presented as having high technologies in specific equipment field, for example, tractors used in harvesting and preparation of biomass for the combustion process in boilers Spanish thermal power plants.

In this European context, Creus (2009) contributes by stating that this continent is using various agricultural waste in the process of power generation by thermoelectric power plants, e.g., biomass from corn, soybean, sunflower, eucalyptus, sorghum, etc. This energy potential encourages large investments in the sector, requiring models of efficient and effective business management. Also according to Creus (2009), Europe demonstrates some models of thermal power plants, such as plant with steam boiler from forest residues of 5 $\mathrm{MWh}, 10 \mathrm{MWh}$, and $20 \mathrm{MWh}$. These plants are evaluated from an economic and financial point of view, as in the case of $5 \mathrm{MWh}$ plant, which requires an initial investment of 7,607.850 million euros, with 20-year period, the capital cost of $2 \%$ per year. After paying all operating expenses, this plant at the end of 20 years, can generate a net present value of approximately 18,848.615 million euros, signaling as a profitable project from the economic and financial point of view. In this context, it is noteworthy that the power cogeneration scenario, concerning projects related to bioenergy in Spain is increasing, forseeing positive scenarios in the renewable energy segment. Thus, in 2005, the receipt was 2.93222 euros cents per Kwh. From 2008 there was an increase 
ranging from at least 5.5396 and at most 16.4213 cents. This growing market can attract new investors in current projects and also the emergence of new projects (CREUS, 2009).

It is important to add that, according to Creus (2009) and the research carried out in a Thermal Power Station with power of $20 \mathrm{MW} / \mathrm{h}$, the results were demonstrated through the evaluation of the project which was developed taking into account of a recovery period of 20 years, based on the depreciation period, according to Table 2: (i) initial investment of $€ 23,700.000$; (ii) capital cost of $7 \%$ per year and other operational and business costs. The demonstrated cash flow identified the payback time only in the 16th year, remaining only four years to an alleged maximization of wealth. In addition, the net present value presented negative in the order of $(10,956.205)^{2}$, assuming a capital cost of $7 \%$ per year. In order to strengthen the position of unfeasible Project, it was also applied the internal rate of return, which was on the order of $4 \%$ per year, proving to be an unfavorable scenario from an economic and financial point of view, regarding the project analyzed.

Ramiro Velasco (2009) also contributes that small installations (thermoelectric plants), with less than 1 MW, may have a more significant economic viability compared to industrial plants with major powers, regarding the benefits of European legislation, as, e.g., financial grants to small plants cogeneration. Therefore, these financial incentives encourage cogeneration of energy from small cogeneration plants in the country. Thus, the Spanish government guarantees the economic and financial viability through the Decree 661/2007 that encourages production and energy cogeneration growth in the European Union.

\section{Research Methodology}

The survey was conducted in a Spanish Thermal power station of the renewable energy sector, treated in this study as a pilot model project II (Spanish thermal power plant), and the main focus of this study was exclusively thermal energy cogeneration converted to electricity from the biomass. The survey took place in the period from 21-11-2008 to 14-12-2009, equivalent to 358 days.

This paper is in an exploratory-descriptive research and delineates in three forms of research: bibliographical, documentary, and case study (GIL, 1994). Therefore, after all the bibliographic and documentary survey, the next stage was the documentary analysis, the preparation of programmed questionnaires and structured interviews. It was listed all productive activities inherent in the powerhouse cost center. Additionally, this paper also included direct observations through visits in the location of research, with the objective of verifying normal events of the company, registering the organized events.

The methodological research process outlined in this paper was the case study, given that this option has as the theoretical basis the description of Yin (2001). The author states that the case study is more appropriate to test well-founded theories, e.g., the capital budget preparation techniques (average rate of return, payback period, net present value, and internal rate of return) (Gitman, 2004; Van Horne, 1993). Thus, to confirm, compare, or extend the theory, there should be a case that meets the conditions to apply the theory to an analysis, which means a significant contribution to the knowledge base and the construction of theories. In addition, the author states that the case study can be used to determine whether the propositions of a theory is correct or if some other alternative set of explanations can be more relevant. Such a study can even help redirect future research in a given segment.

\footnotetext{
${ }^{2}$ In this paper, it was considered as negative all numbers in brackets ().
} 
Regarding the methodology, it was developed a cash flow for capital budget, based on the costs obtained by the pilot model projects II, which were used for the preparation of operational inputs. It is worth noting that the depreciation was treated as a variable that rewarded the burden of income tax, i.e., the depreciation was not restored to the formation of cash flow (operating inputs) for the purpose of rewarding the onus on income tax because the estimated time. Thus, it creates a synthesized and practical method for the preparation of operational inputs of any project.

The initial investment value was based on the real value in euros of the project, and converted into Brazilian real currency on the date of 31-12-2009. Depreciation was also calculated using the straight-line method. According to Yin (2001), and the data collection directed to the case study can be carried out through six different sources: documents, file records, interviews, direct observation, participant observation, and physical artifacts. In addition, the researcher may: (a) use evidence sources that converge on the same set of facts or discoveries; (b) prepare a database to store all information pertaining to the proposed study; (c) develop explicit links between the questions asked, the data collected, and established conclusions. Thus, the case study, possibly, is substantially of higher quality. Thus, the data collection for this study was conducted through questionnaires, interviews, reports assigned by the company, direct observation, and physical artifacts, how to measure the time of production activities.

\section{Research Results}

Regarding data collection, a research (survey) on the factory floor of this company (Thermal Power Station) was performed, in which were identified the most relevant activities, which were responsible for financial resource consumption.

Quantitative data surveyed in plant II were obtained from 21-11-2008 to 14-12-2009, totaling 358 days. In the process of data records were used Excel spreadsheets for data records, with the purpose of filtering and grouping the two periods, in order to demonstrate the total operating costs and investments that period.

The demonstration plant was carried out by city councilor as follows: central heating, distribution network, operation, and users connection. It also argues that the plant is composed of various equipment such as boiler 4,500,000 kcal/h boiler of $600,000 \mathrm{kcal} / \mathrm{h}, 100 \mathrm{~m}^{3}$ storage silo, tray systems for supply, hopper and discharge system, electric pumps, multi-cyclone and smoke purifier, distribution network, and control auxiliary teams.

The analyzed plant system operates through a set of pumps, which make possible to take hot water from the boilers to the users (residential or commercial) via ducts of $3 \mathrm{~km}$. The supply of hot water and heating serves about 250 families, about 1,000 people, representing $10 \%$ of the city's population, 600 school students, government offices and the municipal swimming pool, a multi-sport gymnasium, and some municipal facilities.

The hot water system of the plant at $95^{\circ} \mathrm{C}$ is closed and after use, the water returns almost at a temperature between 85 and $65^{\circ} \mathrm{C}$ (depending on the demand at every moment of the day) to the distribution center. This primary circuit of hot water distribution comprises a pre-isolated pipe, one meter depth along the distribution network, so that the maximum loss of thermal energy is only $0.5^{\circ} \mathrm{C}$.

In Table 1, the revenues are related and its origin is demonstrated within business units during the period.

Most of the revenue was from private buildings cooperatives an amount of $\mathrm{R} \$ 777,177.35$, representing $79.66 \%$ of total revenues of the reporting period. 
Table 1

Revenue Ratio

\begin{tabular}{lll}
\hline Revenues & $€ /$ year (2009) & R\$/year (2009) \\
\hline Cooperatives (corporate) & $311,556.36$ & $777,177.35$ \\
Individuals (consumer) & $40,405.19$ & $100,790.74$ \\
Public subsidies & $39,106.84$ & $97,552.01$ \\
Total & $391,068.39$ & $975,520.10$ \\
\hline
\end{tabular}

Table 2 shows the operating costs of the studied power plant (Plant II) for the period from 21/11/2008 to $14 / 12 / 2009$, equivalent to 358 days.

Table 2

Ratio of Operating Costs

\begin{tabular}{lll}
\hline Description & $€ /$ year $(2009)$ & $\mathrm{R} \$ /$ year $(2009)^{3}$ \\
\hline Electric power consumed in the plant & $75,382.96$ & $188,042.80$ \\
Salaries and wages (production) & $48,947.07$ & $122,098.47$ \\
Social security company (production) & $16,201.48$ & $40,414.60$ \\
Specific clothing (employees) & 118.75 & 296.21 \\
Various materials (production) & 614.99 & $1,534.09$ \\
Telephone (plant) & 257.91 & 643.35 \\
Plant's insurance & $1,563.61$ & $3,900.41$ \\
Several expenses (production) & 374.33 & 933.77 \\
Subtotal of perating costs & $143,461.10$ & $357,863.70$ \\
Institute of diversification and energy saving (IDAE) & $111,418.16$ & $277,932.59$ \\
Thermal power value (estimated) & $1,465,116.00$ & $3,654,731.86$ \\
Total of financial resource in the period analyzed & $1,719,995.26$ & $4,290,528.15$ \\
\hline
\end{tabular}

It should be mentioned that the analytical account called "electricity consumed in the plant, refers to the costs of electricity consumption of plant II, which in this study was treated as equivalence between the energy consumed in this plant and the energy produced in the same plant". This equivalence is justified by the factor that it is producing energy without using fossil fuel, i.e., through the use of forest biomass, which has been treated in this study as a renewable and clean energy.

In Table 2, all operating costs became visible, especially costs relating to electricity and wages, which were the most significant in the period analyzed, which represented $86.66 \%$ of total operating costs presented.

Energy production, which was measured in November and December 2008 totaled 1,149.10 MWh, 275.20 MWh in November 2008, and 873.90 MWh in December 2008.

In short, Table 3 shows the sum of thermal energy production for the period studied (2008-2009).

Table 3

Production on Thermal Energy in the Analyzed Period (2008/2009)

\begin{tabular}{lc}
\hline & Year of $2008 / 2009$ \\
\hline Description & MWh production \\
\hline Total & $6,175.90$ \\
\hline
\end{tabular}

\footnotetext{
${ }^{3}$ http://pt.exchange-rates.org/Rate/EUR/BRL/31-12-2009 (1 EUR = 2.4945 BRL in 31/12/2009).

${ }^{4}$ Financial amortization carried out by IDAE (Investment).
} 
The thermal power production was analyzed from 21-11-2008 to 14-12-2009, totaling 358 days, representing 6,175.90 MWh of energy.

Following the analysis, it is presented in Table 4, which is responsible for exposing the total operating costs and also the total amount of financial resources consumed over the analyzed period.

Table 4

Operating Costs, Investments, and Improvements

\begin{tabular}{lll}
\hline Description & Costs $(€)$ & Costs $(\mathrm{R} \$)$ \\
\hline Production costs & $143,461.10$ & $357,863.70$ \\
Depreciation cost Ac. period (estimated) & $73,255.80$ & $182,736.59$ \\
Opportunity cost (estimated) & $87,402.00$ & $218,024.28$ \\
Total operating costs & $304,118.90$ & $758,624.57$ \\
Investments and improvements & $32,456.37$ & $80,962.41$ \\
Total value of the plant (estimated) & $1,465,116.00$ & $3,654,731.86$ \\
Total value of financial resources in the period & $1,801,691.27$ & $4,494,318.84$ \\
\hline
\end{tabular}

The total operating costs were exposed in Table 4 in the amount of $\mathrm{R} \$ 758,624.57$. This value will be referred in this study as a cost of the provided capacity, which was used to calculate the cost rate of capacity, which covered the activities carried out throughout the production process.

\section{Analysis and Discussion}

The pilot model project II analyzed the industrial plant that consists of two employees who worked eight hours a day, according to the country's legislation in 2009 (DIEESE, 2012). It is worth mentioning that the analysis period was of 358 days, from 21-11-2008 to 14-12-2009.

Table 5 shows the operating profit of the analyzed plant, i.e., confronting revenue and business expenses.

Table 5

Operating Profit

\begin{tabular}{lll}
\hline Description & $€ /$ year (2009) & R\$/year (2009) \\
\hline Total of operating income in the period & $391,068.39$ & $975,520.10$ \\
Subtotal of operating costs in the period & $143,461.10$ & $357,863.70$ \\
Gross profit & $247,607.29$ & $617,656.40$ \\
\hline
\end{tabular}

Operating income was identified in Table 5 in the amount of $\mathrm{R} \$ 617,656.40$, confronting operating revenues with operating costs in the period from 21-11-2008 to 14-12-2009.

The energy production, which was measured in November and December 2008 totaled 1,149.10 MWh, 275.20 MWh in November 2008, and 873.90 MWh in December 2008.

It should be noted that in this study were used only the operating costs absorbed in the production process, i.e., the financial resources needed to produce thermal energy (heat and hot water).

Investments and improvements are not part of the operating costs context, because they are part of another thematic group treated for accounting, which are denominated investments, which consume financial resources with the intention to assign improvements in long-term, i.e., in the following years.

The carbon credit calculation was made on the basis of thermal energy production of 6,175.90 MWh in the analyzed period, multiplied by 0.3 , totaling 1852.77 carbon credit ton, which was sold at the time, for the average price of $\mathrm{R} \$ 20.00$ per ton, generating gross revenue of $\mathrm{R} \$ 37,055.40$. 
Figure 1 shows the path of total operating costs, detailing the expenses as follows: production cost, depreciation cost, and opportunity cost.

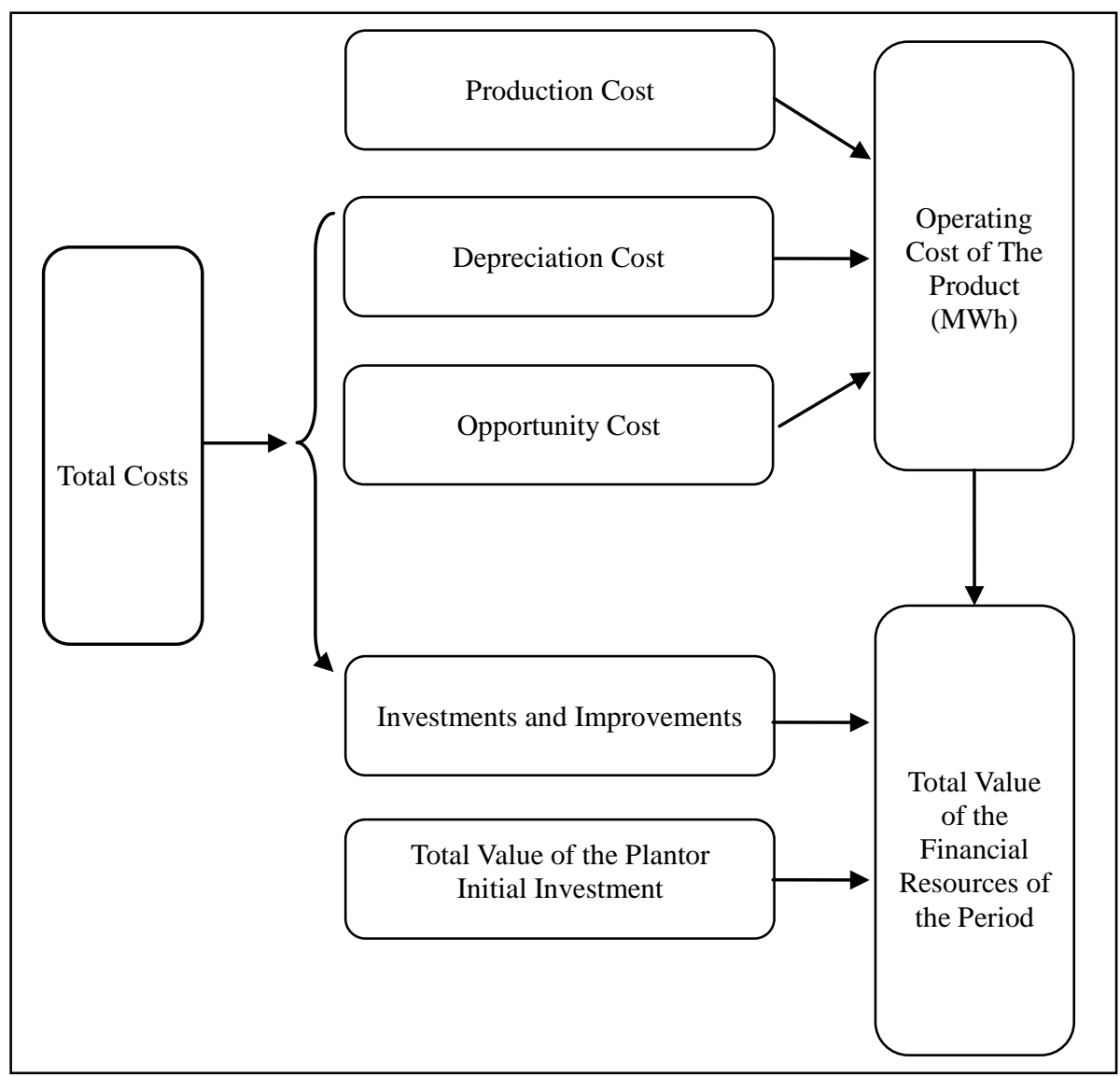

Figure 1. Total cost of the sugar-energy sector.

Figure 1 made visible the path of financial resources to the cost object (MWh), the resources consumed in fixed assets was added (non-current assets), which were treated as investments, improvements, and total value of the plant, or initial investment pilot model project II.

Table 6 shows the ratio revenues/operating costs represented by the quantitative data of the reporting period.

Table 6

Revenue/Operating Costs

\begin{tabular}{llll}
\hline Description & $\begin{array}{l}\text { Quantity } \\
(\mathrm{MWh})\end{array}$ & $\begin{array}{l}\text { Revenue } \\
(\mathrm{R} \$)\end{array}$ & $\begin{array}{l}\text { Operating cost } \\
(\mathrm{R} \$)\end{array}$ \\
\hline $\begin{array}{l}\text { Energies production } \\
\text { Operating revenues }\end{array}$ & $6,175.90$ & $975,520.10$ & \\
$\begin{array}{l}\text { Revenue (carbon credit) } \\
\text { Operating cost }\end{array}$ & & $37,055.40$ & $758,624.57$ \\
Total revenue/operating cost & & $1,012,575.50$ & $758,624.57$ \\
\hline Operating profit & $253,950.93$ & & \\
\hline
\end{tabular}

5 The calculation of the Carbon Credit was held on the following formula: 6,175.90 MWh generated, multiplied by 0.30 , equal to 1,852.77 ton of Carbon Credit, with an average selling price of $\mathrm{R} \$ 20.00$ in analyzed period. 
Table 6 presented the ratio revenue/project operating costs of pilot model project II, which were distributed as follows: thermal energy production in the amount of 6,175.90 MWh, generating a gross revenue of $\mathrm{R} \$ 975,520.10$, and representing $\mathrm{R} \$ 157.95$ per MWh generated.

On the information described, it can be said that each MWh could be sold for $\mathrm{R} \$ 157.95$ during the period analyzed. Moreover, the carbon credits could generate revenue, demonstrating that each generated MWh could raise revenues of $\mathrm{R} \$ 6.00$ ( $\mathrm{R} \$ 37,055.40$ divided by 6,175.90 MWh). Thus, Table 6 shows, as well, an gross operating revenues of $\mathrm{R} \$ 1,012,575.50$ and operational costs of $\mathrm{R} \$ 758,624.57$, calculating an operating profit of $\mathrm{R} \$ 253,950.93$ over the analyzed period (358 days).

Operating costs were approved in the amount of $\mathrm{R} \$ 122.8363$, as follows: Employees dedicated 19.8967 minutes, which is equivalent to $1 \mathrm{MWh}$ consumed in the plant, multiplying the capacity cost rate of $\mathrm{R} \$ 6.173703$, and it was found that the operating unit cost of thermal power in the amount of $\mathrm{R} \$ 122.8363$. In addition, it was found, also, the total operating cost of $\mathrm{R} \$ 758,624.57$ (multiplying $\mathrm{R} \$ 122.8363$ by $6,175.90$ MWh of energy).

Table 7 displays the calculations made to determine the depreciation cost, opportunity cost, and capital cost.

Table 7

Capital Cost Regarding the Analyzed Period

\begin{tabular}{llll}
\hline $\begin{array}{l}\text { Book value-beginning } \\
\text { of the analyzed period }\end{array}$ & $\begin{array}{l}\text { (1) Depreciation cost } \\
(5 \%)\end{array}$ & $\begin{array}{l}\text { (2) Opportunity cost } \\
(5.9573 \%)\end{array}$ & $\begin{array}{l}\text { (1+2) Capital cost in the period } \\
(10.9573 \%)\end{array}$ \\
\hline $\mathrm{R} \$ 3,654,731.86$ & $\mathrm{R} \$ 182,736.59$ & $\mathrm{R} \$ 218,024.28$ & $\mathrm{R} \$ 400,760.87$ \\
\hline
\end{tabular}

From a financial point of view, quantitative data were presented as follows: initial investment of $\mathrm{R} \$ 3,654,731.86$, operational inputs of $\mathrm{R} \$ 253,950.93$ with 20-year recovery period, and capital cost $10.95 \%$.

The depreciation was treated according to the recovery period project (20 years), calculated using the straight-line depreciation method, which considers the loss of value as equal fractions of $5 \%$ over the estimated recovery period (20 years). In this sense, the opportunity cost was calculated from Kaplan and Anderson's theory (2008), which could treat forest biomass as a product that could possibly be sold by the average monetary value of $\mathrm{R} \$ 20.00$ per ton in the period studied. This allowed us to estimate the plant possibly consumed (burned) 2,182.05 tons of forest biomass, which could be sold for $\mathrm{R} \$ 99.78$, equivalent to $40 €$ (euros), representing a value of $\mathrm{R} \$ 218,024.28$ in the period studied. It is worth adding that in the Spanish case the opportunity cost would be enough to supply the generated inflation in the analyzed period $(0.794 \%)^{6}$.

To determine the opportunity cost of this study, it was estimated a respective monetary value of $\mathrm{R} \$ 218,024.28$, divided by $\mathrm{R} \$ 3,654,731.86$ (book value of the analyzed plant), representing an opportunity cost of $5.95 \%$.

Then, it was found the capital cost, which was identified after the sum of depreciation and opportunity cost ( $\mathrm{R} \$ 182,736.59+\mathrm{R} \$ 218,024.28)$, totaling $\mathrm{R} \$ 400,461.53$, which was divided by the book value of the analyzed plant ( $\mathrm{R} \$ 3,654,731.86)$, generating a capital cost of $10.95 \%$.

The payback found in this project (biomass power plant) was 14.39 years. Thus, the pilot model project II would be feasible from an economic and financial point of view, therefore, the project payback period is below of its project depreciation period.

\footnotetext{
${ }^{6} \mathrm{http} / / /$ es.global-rates.com/estadisticas-economicas/inflacion/2009.aspx.
} 
It should be noted that the project managers generally stipulate a recovery period of lower initial investment than the depreciation period (20 years). In this case, one could set a maximum initial investment recovery in the fifteenth year (15). This information contributed to stating that the referred project in question would be viable according to the result of the payback (14.39 years), i.e., operating entries would be sufficient to recover the initial investment capital at zero cost.

Following the project review in question, it was used the second technique of elaboration of the capital budget, called net present value (NPV), which identified a NPV of R\$1,625,086.86. This result indicates that the analyzed project would not be feasible based on the NPV method. Ultimately, the issue of capital budgeting techniques, applied the internal rate of return (IRR), which reported a percentage of 3.36, indicating that the hurdle rate would infer the rate required by the company (capital cost) and so the project would not be feasible based on the method of IRR.

The pilot model project II traced the economic and financial feasibility in the studied plant from the hypothesis of thermal power generation equivalent to 7,699.08 MWh that could generate an operating income of $R \$ 1,262,264.16$ and consequently operational inputs of $R \$ 503,639.59$ over 20 years. From an economic and financial point of view, according to the techniques of capital budgets, would result: payback of seven years and three months, NPV of R $\$ 369,064.98$, and IRR of $12.46 \%$. Therefore, managers have to make a user raising campaign corresponding $24.66 \%$, i.e., in the same proportion to the used capacity $(25 \%)$.

\section{Conclusions}

Given the results shown in this article is relevant to mention that the pilot model project II tracked the economic and financial viability in the analyzed industrial plant (Spanish thermal power plant) in the following cases:

The economic and financial viability was identified from thermal energy production hypothesis equivalent to $7699.08 \mathrm{MWh}$, which resulted in the following indicators: payback period of seven years and three months, NPV of R $\$ 369,064.98$, and IRR of $12,46 \%$. Therefore, managers would have to make a user raising campaign corresponding $24.66 \%$, taking into account of an unused capacity of $25 \%$. This scenario would only be achieved through the following financial data: initial investment of $\mathrm{R} \$ 3,654,731.86$, operating income of $\mathrm{R} \$ 1,262,264.16$, operational inputs of $\mathrm{R} \$ 503,639.59$, and capital cost of $10.95 \%$ over 20 years.

It is worth mentioning that the pilot model project II also analyzed the economic and financial viability indicators in accordance with the normal operation of the plant studied in the period from 21-11-2008 to 14-12-2009, as follows:

The calculated payback was 14.39 years, which would be feasible from economic and financial point of view. It should be noted that the project managers generally stipulate a recovery period of lower initial investment than the depreciation period (20 years). In this case, one could set a maximum initial investment recovery in the fifteenth year (15). This information contributed to stating that the referred project in question would be viable according to the result of the payback (14.39 years), i.e., operating inputs would be sufficient to recover the initial investment capital at zero cost.

Following the analysis, it was used the second method of preparation of the capital budget, called net present value (NPV), which identified a NPV of R $\$ 1,625,086.86$. This result indicates that the analyzed project would not be feasible based on the NPV method. Ultimately, the issue of capital budgeting techniques, it was applied the internal rate of return (IRR), which reported a percentage of 3.36, indicating that the hurdle rate 
would infer the rate required by the company (cost capital) and so the project would not be feasible based on the method of IRR.

It was concluded that the pilot model project II (Spanish thermal power plant) may require adjustments from the management point of view, especially on the financial issue, so it can be more efficient and effective in their management, bearing in mind the perpetuity of the company without the need for new insertions of financial subsidies, either equity or debt capital.

\section{References}

Álvarez, L. J. (1992). Contabilidad Financiera. Madrid, España: Editorial Everest, S.A.

Creus, A. S. (2009). Energías Renovables (2nd ed.). Madrid: Ediciones Ceysa, Madrid.

Dieese. (2010). Departamento Intersindical de Estatisticas e Estudos Socioeconômicos. Disponível em: http://www.dieese.org.br/notatecnica/notatec91JornadaTrabalhoMundo.pdf (Acesso em: 2 out. 2012).

Emery, D., \& Finnerty, D. J. (2000). Administración Financiera Corporativa. 1. ed. México: Pearson Educación.

EurObserv'ER. (2012). Disponivel em: <http://www.eurobserv- er.org/pdf/press/year_2012/RES/English.pdf> (Acesso em: 08 jan. 2013).

Gil, A. C. (1994). Métodos e Técnicas de Pesquisa Social. São Paulo: Atlas.

Gitman, J. L. (2004). Princípios de Administração Financeira (10th ed.). São Paulo: Editora Pearson.

IDAE. Instituto para la Diversificación y Ahorro de la Energía. (2011). Madrid: Plan de Energías Renovables (PER) 2011-2020. Disponível em:< http://www.idae.es/index.php/id.670/relmenu.303/mod.pags/mem.detalle> (Acesso em: 10 abr. 2012).

Johnson, R. W \& Melicher, R. W. (1989). Administración Financiera (4th ed.). México: Editrial Continental.

Kaplan, R. S., \& Anderson, S. (2004). Time-driven activity-based costing. Harvard business review, 82 (11), 131-138.

Kaplan, R. S., \& Anderson, S. R. (2007). Custeio Baseado em Atividade e Tempo. O caminho Prático e Eficaz para aumentar a Lucratividade. Rio de Janeiro: Elsevier.

Kaplan, R. S., \& Anderson, S. R. (2008). Costes Basados En El Tiempo Invertido por Actividad. Una Ruta Hacia Mayores Beneficios. Barcelona: Ediciones Deusto.

Martins, E. (2003). Contabilidade de Custos: inclui o ABC (8th ed.). São Paulo: Atlas.

Ruíz Martinez, Ramon J., \& Gil Corral, Antonio Mª (2001). La Planificación Financiera de la Empresa. Madrid: Instituto Superior de Técnicas y Prácticas Bancarias.

Ramírez, R., \& Alfonso, A. (2011). Análisis Económico financiero de la Empresa. Un Análisis desde los datos Contables. Madrid: Ibergarceta Publicaciones.

Ramiro Velasco, F. Estudio de Viabilidad y Diseño de una Planta de Cogeneración para una Industria Cárnica. Máster. Universidad Carlos III de Madrid Escuela Politécnica Superior, 2009.

Redondo, A., \& Pajares, J. (1999). Las nuevas medidas de creación de valor: panorama e interrogantes. Revista Boletín AECA, 50, 39-41, 1999. ISSN: 1136-1069.

Ross, S. A., Randolph, W., Westerfield, \& Jeffrey, F. Jaffe. (2009). Administração Financeira (2nd ed.). 9. Reimpr. São Paulo: Atlas.

Van Horne, J. C. (1993). Administración Financiera (2nd ed.).México: Prentice Hall Hispanoamericano, México.

Yin, R. K. (2001). Estudo de caso: Planejamento e Métodos (2nd ed.). Porto Alegre: Bookman. 